\title{
Vertical Transport of Chlorinated Hydrocarbons by Sedimentation of Particulate Matter in Kiel Bight*
}

\author{
C. Osterroht and V. Smetacek
}

Institut für Meereskunde an der Universität Kiel, Düsternbrooker Weg 20, D-2300 Kiel 1, Federal Republic of Germany

\begin{abstract}
Particulate matter settling out of the water column was collected continuously over a two-year period by means of multisample sediment traps in the coastal waters of the Western Baltic Sea. The content of PCBs and organochlorine pesticides of this matter was determined and compared with its dry weight, and with its organic carbon, nitrogen, and plant pigment content. The pesticide content of this material was highly variable and a marked decline in absolute concentrations was present from 1975-1977; in most samples from 1977, pesticide content was below detection limit. For PCBs, a distinct annual cycle was observed which was inversely related to the rates of sedimentation of seston; highest absolute values for PCBs in each year were recorded during the summer. The input rates of PCBs to the sediments ranged between $112.10^{3}$ and $24.10^{3} \mathrm{ng} \mathrm{m}^{-2} \mathrm{Y}^{-1}$.
\end{abstract}

\section{INTRODUCTION}

Chlorinated hydrocarbons enter the surface layers of the sea through atmosphere, land drainage and shipping. Sources and fate of these pollutants in the sea have been discussed by several authors (Holden, 1970; Walsh, 1972; Harvey et al., 1973; Dawson and Riley, 1977). The removal of these compounds from the surface layer and introduction to deeper layers and/or sediments is effected by various agencies such as migrating organisms, vertical mixing processes and adsorption onto sedimenting particulate matter. The latter process is a major transport pathway in the sea, and life below the euphotic zone is dependent for its energy requirements on material derived in this way. The sedimenting particles may be living organisms (plankton), dead organic matter (organic detritus) as well as inorganic particles (inorganic seston). As a result of adsorption, it is possible for any of these categories of particulate matter to contain chlorinated hydrocarbons (Weil et al., 1973; Derenbach et al., 1978). Thus, sedimentation is bound to be an important mechanism by which pollutants introduced into the surface layer will be dissipated throughout the marine ecosystem.

\footnotetext{
' Publication No. 248 of the 'Joint Research Program' at Kiel University (Sonderforschungsbereich 95 der Deutschen Forschungsgemeinschaft).
}

Quantity and composition of the particulate matter depends on both hydrographic regime and seasonal cycle of plankton (Smetacek et al., 1978). Therefore, it can be assumed that the quantity of chlorinated hydrocarbons transported vertically will vary seasonally, depending not only on input rate to the sea surface, but also on quantity and composition of the material sinking out of this layer.

The aim of the present investigation was to assess the amount of chlorinated hydrocarbons reaching the sediments in sinking organic matter during the course of two years, and to ascertain the presence of seasonal trends, possibly linked to factors controlling the sedimentation process. This investigation was carried out within the framework of the Special Research Project 95 (SFB 95) at Kiel University, investigating the interaction between sea and sediments in the SouthWestern Baltic Sea, and DFG project Eh 39/17. Sediment traps were employed to collect the material analyzed in the investigation. The investigation site the 'Hausgarten' of the SFB 95 project - was situated at the entrance of a shallow fjord, about a nautical mile from the coast. Land run-off into Kiel Bight is minimal as the watershed in Schleswig-Holstein lies close to the eastern coast. Much of the land area surrounding Kiel Bight is under cultivation and no major industrial centers are present in the region.

The hydrography of Kiel Bight is fairly well-known (e. g. Bodungen, 1975; Lenz, 1977). It is characterized 
by influxes of low salinity water from the Baltic Sea proper and of higher salinity water from the Kattegat. The SW corner of Kiel Bight, where the 'Hausgarten' is situated, is well away from the major pathway of water exchange and the residence time of water here is longer than elsewhere in the region. The water column is generally homogeneous during winter and strongly stratified during summer, with a halocline at a depth of 8-14 m. Plankton ecology in relation to seasonal cycles of suspended particulates and sedimentation rates at the investigation site and elsewhere in Kiel Bight has been the subject of many papers (e. g. Krey, 1961; Zeitzschel, 1965; Lenz, 1974; Bodungen et al., 1975; Smetacek and Hendrikson, 1979).

\section{MATERIAL AND METHODS}

Sedimenting material was collected at the 'Hausgarten' by means of multisample sediment traps that enable a short-term resolution of sedimentation rates to be made (Zeitzschel et al., 1978). Two traps were suspended, one at $2 \mathrm{~m}$ and the other at $5 \mathrm{~m}$ above the bottom at water depth of $20 \mathrm{~m}$. The $2-\mathrm{m}$ trap was deployed from November 1975 to December 1977; the 5-m trap from March 1976 to December 1977. Until December 1976, collections of sedimenting material were made at 2-d intervals; 4 -d intervals were used thereafter.

The material collected in each of the glasses of the traps was strained through a $300 \mu \mathrm{m}$ gauze to remove larger zooplankton and then suspended in a known volume of filtered sea water. Subsamples for analysis were pipetted from this suspension, kept homogeneous by agitation.

The dry weight (DW) of particles $<300 \mu \mathrm{m}$ was determined on precombusted Whatman GF/C filters as described by Lenz (1977).

Particulate organic carbon (POC) and nitrogen (PON) on the filters were measured with a CHNAnalyzer (Hewlett Packard, 185 B) after pre-treatment in the sample boats with diluted $\mathrm{HCl}$ to remove carbonate.

Chlorophyll $a$ and phaeopigment analyses were carried out as recommended by UNESCO (1966), using a cell mill to homogenize the samples (Derenbach, 1969). Spectrophotometric equations given by Lorenzen (1967) were used for evaluating chlorophylls and phaeopigments. As chlorophyll degradation to phaeopigment occurred in the collecting glasses, both values were added together and are referred to as chlorophyll-a-equivalents (chl-a-equiv.) below. Total carotenoids were estimated from the absorption at $480 \mathrm{~nm}$ as suggested by Strickland and Parsons (1972).
Chlorinated hydrocarbon levels present in 2-d samples were below detection limit; therefore, a number of samples (the number depending on the dry weight content) had to be pooled for each analysis. Five pooled samples were analyzed for each year. The filters were extracted with a mixture of acetone-water ( $3: 2$ by volume) in a Soxhlet apparatus for $6 \mathrm{~h}$. The extracts were concentrated in a rotary evaporator until most of the acetone had been evaporated, and the remaining aqueous solution was extracted three times with small amounts of hexane. The combined hexane phases were successively shaken with distilled water, concentrated sulfuric acid, distilled water again, reduced to a small volume (200-300 $\mu 1)$ and fractionated by liquid-liquid chromatography. The latter was performed on a column of $3.5 \%$ deactivated silicagel (0.04-0.63 $\mathrm{mm}$ grain size) by elution with hexane followed by hexane-ether $(9+1)$ to give two fractions: the first containing the PCBs and $\mathrm{pp}^{\prime}$-DDE, and the second the rest of the organochlorine pesticides. Both fractions were evaporated to $1 / 10$ of their volume to give an appropriate concentration for the linear range of the EC-detector, when injecting a $10 \mu \mathrm{l}$ aliquot into the GC. For details see Osterroht (1977).

Surface sediments from the vicinity of sediment traps were sampled with a bottom corer. After freezing, the upper $1 \mathrm{~cm}$ sediment layer was sliced off and desiccated in a drying chamber at $80^{\circ} \mathrm{C}$ for $3 \mathrm{~h}$. After weighing, the dried sediments were extracted by the same procedure described above.

Gas chromatographic conditions: Chromosorb W AW-DMCS was deactivated with $6 \%$ Carbowax according to the method of Aue (Aue et al. 1973, 1974) and coated separately with both $2 \%$ OV 101 and $2 \%$ QF-1 as stationary phases. The two packings were mixed in equal portions and packed into micropackcolumns (i. d. $0.8 \mathrm{~mm}, 1.50 \mathrm{~m}$ length). The $5730 \mathrm{~A}$ Hewlett-Packard GC was equipped with a pulsed ECD and connected to a $3380 \mathrm{~A}$ integrator. Quantitative evaluation was achieved with the aid of an external standard (Clophen A60). Five of the major peaks arising from the PCBs were measured.

All data were calculated on the basis of results from aliquots for the whole sediment traps per day, corresponding to the fallout from one square meter of surface per day to make them comparable to the other parameters.

\section{RESULTS}

Data for sedimentation rates of organochlorine compounds from the two traps are given in Table 1 . There is a striking decline in the announts of pesticides settling out of the water column during the course of the 
Table 1. Input rates of PCBs and organochlorine pesticides into sediment traps in $\mathrm{ng} \mathrm{m}^{-2} \mathrm{~d}^{-1}$. Values at $2 \mathrm{~m}$ and $5 \mathrm{~m}$ are from traps suspended $2 \mathrm{~m}$ or $5 \mathrm{~m}$ above the bottom. - no data

\begin{tabular}{|c|c|c|c|c|c|c|}
\hline Period & PCBs & Lindane & Dieldrin & DDE & DDD & DDT \\
\hline \multicolumn{7}{|l|}{$2 \mathrm{~m}$} \\
\hline 5. XI. - 16. XII. 75 & 844.6 & 1986.7 & 546.3 & - & - & - \\
\hline 9. I. -29. II. 76 & 459.3 & 571.8 & 100.0 & - & - & - \\
\hline 1. III. - 29. IV 76 & - & 150.7 & 8.0 & - & 1.8 & - \\
\hline 29. IV. -10. VIII. 76 & 318.2 & 85.9 & 216.7 & 65.0 & 154.7 & 112.1 \\
\hline 10. VIII. -22. IX. 76 & 758.3 & - & - & 243.3 & - & - \\
\hline 5. X. -23. XI. 76 & 457.8 & 146.7 & 101.2 & - & 96.1 & 10.1 \\
\hline 28. XII. $76-28$. II. 77 & - & - & - & - & - & - \\
\hline 28. II. -30 . IV. 77 & 67.5 & - & - & - & - & - \\
\hline 8. V. -29. VIII. 77 & 124.3 & - & - & - & - & - \\
\hline 30. VII. $-17 . X .77$ & 168.4 & - & - & - & - & - \\
\hline 17. X. -22. XII. 77 & - & - & - & - & - & - \\
\hline \multicolumn{7}{|l|}{$5 \mathrm{~m}$} \\
\hline 1. M. $-22 . I V .76$ & 550.8 & 137.7 & 7.3 & - & 1.8 & - \\
\hline 29. IV. -10. VIII. 76 & 175.4 & - & - & 17.8 & - & - \\
\hline 10. VIII. -22 . IX. 76 & 363.6 & - & - & 86.2 & - & - \\
\hline 22. IX. -23. XI. 76 & 196.4 & - & 10.1 & - & 10.1 & \\
\hline 23. XI. -28. XII. 76 & - & - & - & - & - & - \\
\hline 28. XII. $76-28$. II. 77 & - & - & - & - & - & - \\
\hline 28. II. $-4 . \vee 77$ & 68.5 & - & 9.1 & - & 9.1 & - \\
\hline 8. V. - 1. VIII. 77 & 137.7 & - & - & - & - & - \\
\hline 2. VIII. -23. IX. 77 & 254.4 & - & - & - & - & - \\
\hline 23. IX. -10. XII. 77 & 78.3 & - & - & - & - & - \\
\hline
\end{tabular}

Table 2. Sedimentation rates of seston (dry weight), particulate organic carbon (POC) and nitrogen (PON), chlorophyll a equivalents (chl.-a-equiv.) and total carotenoids (carot.) in $\mathrm{mg} \mathrm{m}^{-2} \mathrm{~d}^{-1}$. Values at $2 \mathrm{~m}$ and $5 \mathrm{~m}$ are from traps suspended $2 \mathrm{~m}$ or $5 \mathrm{~m}$ above the bottom

\begin{tabular}{|c|c|c|c|c|c|}
\hline Period & Seston & $\mathrm{POC}$ & PON & Chl.-a equiv. & Carot. \\
\hline \multicolumn{6}{|l|}{$2 m$} \\
\hline 5. XI. -16 . XII. 75 & 5584 & 362 & 41 & 2.4 & 1.0 \\
\hline 9. I. -29 . II. 76 & 16476 & 707 & 93 & 5.4 & 2.8 \\
\hline 1. III. -29. IV. 76 & 4050 & 257 & 32 & 4.4 & 1.5 \\
\hline 29. IV. - 10. VIII. 76 & 797 & 92 & 10 & 0.6 & 0.3 \\
\hline 10. VIII. -22. IX. 76 & 3960 & 311 & 41 & 2.7 & 1.8 \\
\hline 5. X. -23. XI. 76 & 6188 & 411 & 41 & 2.4 & 2.0 \\
\hline 28. XII. $76-28$. II. 77 & 5436 & 223 & 28 & 1.5 & 0.9 \\
\hline 28. II. -30. IV. 77 & 2051 & 147 & 15 & 2.8 & 1.1 \\
\hline 8. V. - 29. VIII. 77 & 376 & 41 & 5 & 0.4 & 0.2 \\
\hline 30. VIII. - 17. X. 77 & 1658 & 154 & 16 & 3.8 & 1.5 \\
\hline 17. X. -22. XII. 77 & 8419 & 371 & 39 & 2.2 & 1.2 \\
\hline \multicolumn{6}{|l|}{$5 \mathrm{~m}$} \\
\hline 1. III. - 29. IV. 76 & 3083 & 226 & 27 & 3.1 & 1.0 \\
\hline 29. IV. -10 . VIII. 76 & 495 & 65 & 7 & 0.7 & 0.2 \\
\hline 10. VIII. -22. IX. 76 & 2787 & 282 & 33 & 3.9 & 2.5 \\
\hline 22. IX. -23. XI. 76 & 3413 & 190 & 27 & 2.1 & 1.3 \\
\hline 23. XI. -28. XII. 76 & 4974 & 178 & 25 & 2.9 & 1.5 \\
\hline 28. XII. $76-28$. II. 77 & 2830 & 118 & 15 & 0.8 & 0.4 \\
\hline 28. II. -4 . V. 77 & 2648 & 159 & 18 & 3.5 & 1.4 \\
\hline 8. V. - 1. VIII. 77 & 556 & 71 & 9 & 0.9 & 0.4 \\
\hline 2. VIII. -23. IX. 77 & 375 & 49 & 6 & 0.8 & 0.2 \\
\hline 23. IX. -10. XII. 77 & 1848 & 177 & 22 & 1.6 & 0.9 \\
\hline
\end{tabular}



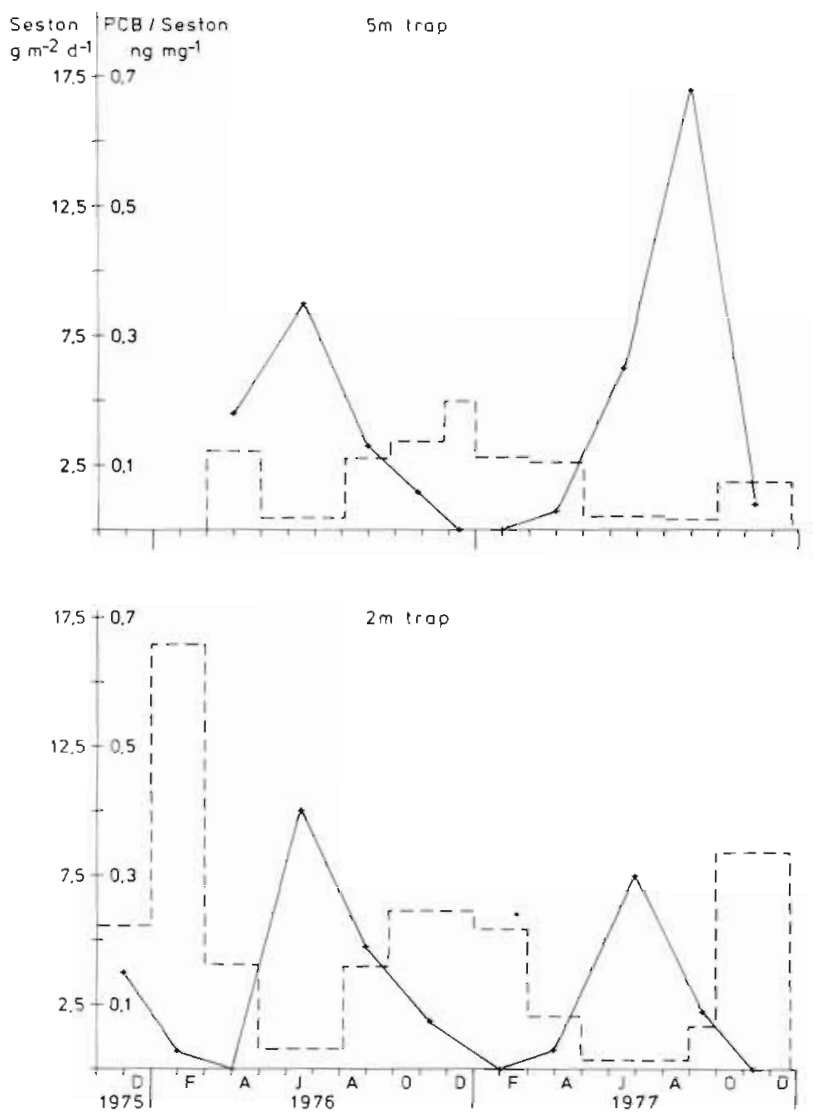

Fig. 1. Histograms: sedimentation rates of seston dry weight $\left(\mathrm{g} \mathrm{m}^{-2} \mathrm{~d}^{-1}\right)$ averaged for periods when samples were pooled for analysis of PCBs. Curves: ratios of PCBs per dry weight (ng: $\mathrm{mg}$ ). $2 \mathrm{~m}$ and $5 \mathrm{~m}$ : results from traps $2 \mathrm{~m}$ or $5 \mathrm{~m}$ above the bottom
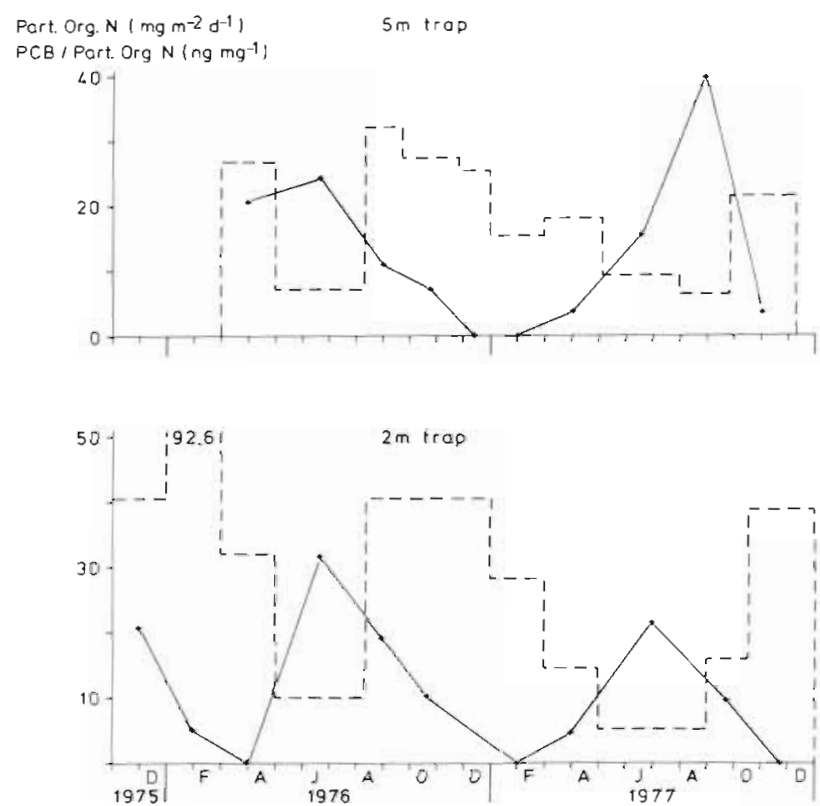

Fig. 3. Sedimentation rates of particulate organic nitrogen (PON $\mathrm{mg} \mathrm{m}^{-2} \mathrm{~d}^{-1}$ ) and ratios PCB : PON (ng : $\mathrm{mg}$ ) in histograms and curves, respectively. Further details as in Figure 1

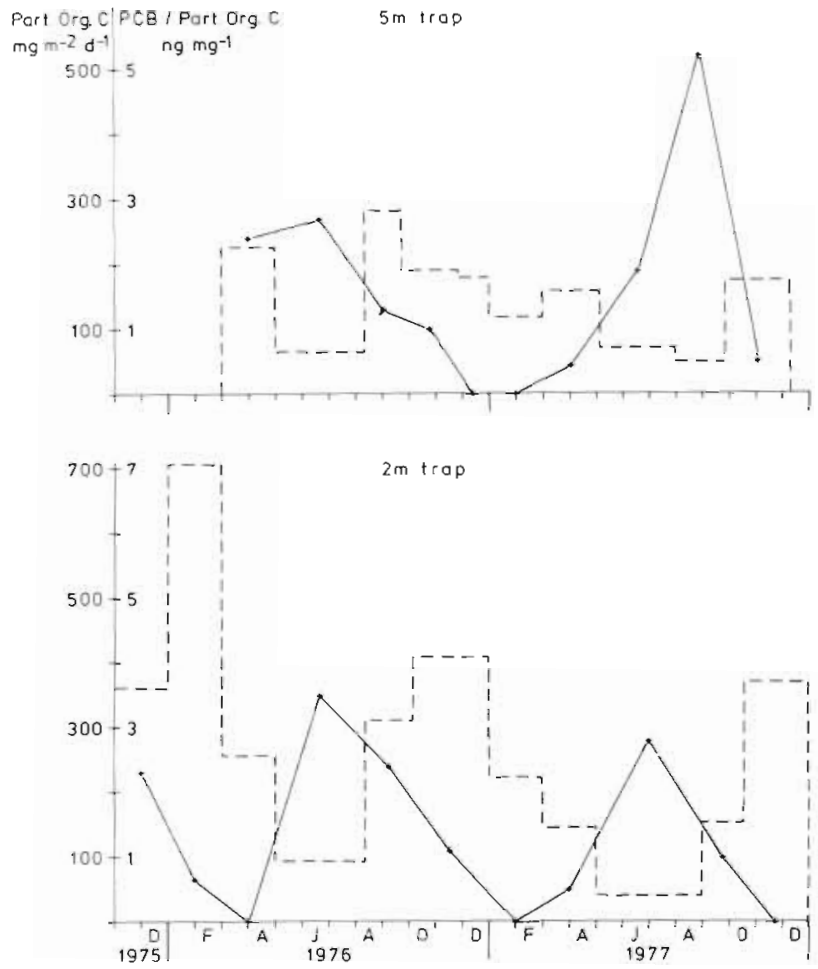

Fig. 2. Sedimentation rates of particulate organic carbon (POC $\mathrm{mg} \mathrm{m}^{-2} \mathrm{~d}^{-1}$ ) and ratios PCB : POC (ng : $\mathrm{mg}$ ) in histograms and curves, respectively. Further details as in Figure 1

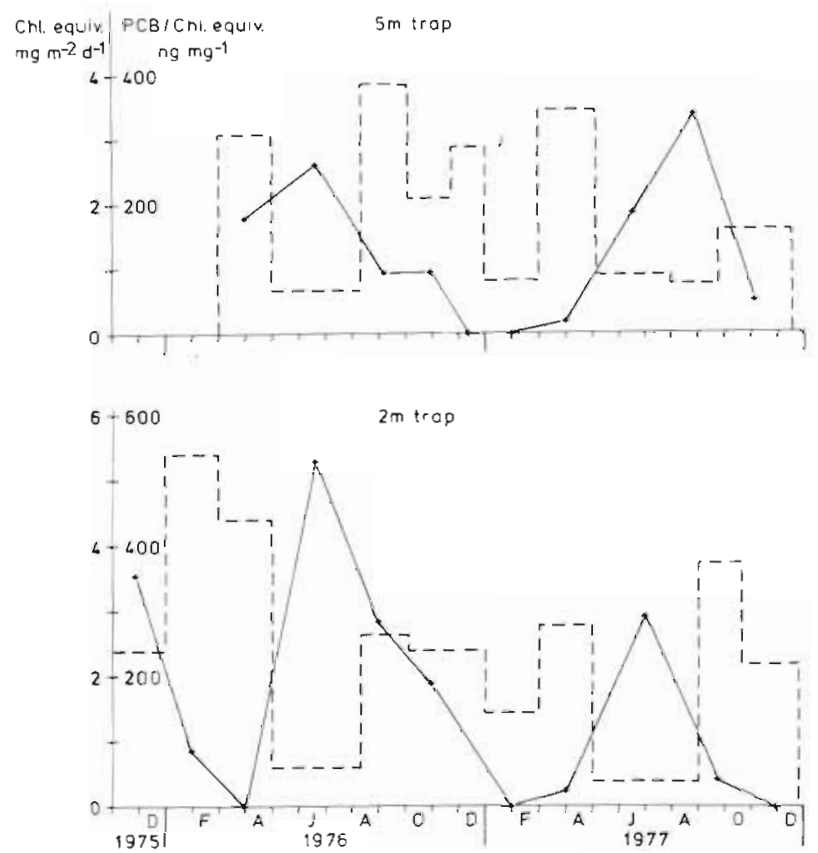

Fig. 4. Sedimentation rates of chlorophyll a equivalents ( $\mathrm{mg} \mathrm{m}^{-2} \mathrm{~d}^{-1}$ ) and ratios PCB : chl.-a-equiv. in histograms and curves, respectively. Further details as in Figure 1 
investigation period, with practically zero values recorded during 1977 from both traps. The position is different for the PCBs where substantial amounts were recorded in 1977 although these values are generally lower than those of 1976.

Sedimentation rates of the particulate matter and its various components recorded by the two traps for the period investigated are given in Table 2 and shown in histogram form in Figures 1-4. Highest and lowest annual rates were found for both traps during winter and summer, respectively, with intermediate values in spring and autumn. No relationship between sedimentation rates of pesticides and particulate matter is present, but for PCBs an inverse relationship between particulate matter and its content of PCBs is apparent. This has been shown in the curves depicting the ratios of the dry weight of particulate matter as well as its various components to the content of PCBs also given in Figures $1-4$. A very striking cycle is present in these curves which is common to traps from both depths, apart from a slight phase shift in the summer of 1977 . This cycle appears to be seasonal and, in general, it can be stated that maxima are present in summer and minima in winter. However, there are temporal shifts in this pattern from one year to the next: the first minimum is in February/March, the other two in midwinter; the 1976 and 1977 peaks are in June/July and July/September, respectively. From Table 1 it can be seen that the absolute amounts of PCBs in summer were higher, concomitant with lower rates of sedimentation of particulate matter (Table 2), than during the rest of the year. The presence of this distinct seasonal cycle may be related either to the rates of input of PCBs into the system or to ecological factors associated with the seasonal cycle of sedimentation in Kiel Bight.

PCBs entering Kiel Bight may originate from several sources, all of which are difficult to quantify, as Kiel Bight receives water from the Baltic Sea as well as the North Sea.

The seasonal cycle in the quantity and composition of the particulate matter and its relationship to the plankton ecology and hydrography of Kiel Bight is described in greater detail elsewhere (Smetacek, in press); only a brief description is given here. Data on plankton ecology have been taken from Bodungen (1975), Smetacek (1975) and Smetacek and Hendrikson (1979).

During the winter months primary production is at its lowest although the sedimentation rates are the highest of the year. These high sedimentation rates are evidently the result of resuspension of surface sediment as the hydrographical conditions (homogeneous water column) and meteorological (prolonged stormy weather) factors combine to produce higher turbulence levels in the water column in winter than at other times of the year. This resuspension is also reflected in the greater amounts collected by the lower trap during winter. When resuspension is not of importance, amounts collected by the two traps are much more similar.

Much of the biomass produced by the spring phytoplankton bloom in March/April sediments out of the water column and is clearly recognizable in sediment trap material by increases in the proportions of carbon, nitrogen and pigments relative to the dry weight. Sedimentation rates in summer are generally low, although production rates and plankton biomass levels are comparatively high throughout this period. Organic matter in the water column is apparently turned over more rapidly than it can sediment, the former process being aided not only by higher temperatures but also by the large zooplankton stocks present in the summer months. In autumn, Kiel Bight plankton is characterized by a large population of dinoflagellates (various Ceratium spp.) to which zooplankton do not appear to be partial. Organic carbon present in this population sediments out in a fashion similar to the spring bloom. Thereafter, the winter situation prevails. Because of lumping of data, this pattern is not so evident from the histograms given in Figures 1-4, but the trend can be discerned.

The annual cycle described above was found both in 1976 and 1977, although the absolute amounits of sedimented matter differed considerably from year to

Table 3. Amounts of PCBs and organochlorine pesticides in two surface sediment samples from April 1978, expressed as ng $\mathrm{g}^{-1} \mathrm{~d} r \mathrm{y}$ weight of sediment

\begin{tabular}{|lcc|}
\hline PCBs & 8.4 & 10.8 \\
Lindane & 2.4 & 3.2 \\
Dieldrin & 0.9 & 1.3 \\
DDE & 1.3 & 0.47 \\
DDD & - & - \\
DDT & 1.1 & 1.5 \\
\hline
\end{tabular}

year. Thus, during 1976, a total of $61 \mathrm{~g} \mathrm{C} \mathrm{m}^{-2}$ was collected by the lower trap during the growth season of plankton (March-October), whereas in 1977 only $22 \mathrm{~g} \mathrm{C} \mathrm{m}^{-2}$ was recorded for the same period.

Concentrations of chlorinated hydrocarbon in surface sediments are shown in Table 3 . The PCB content of the sediment on a dry weight basis is much lower than that of the particulate material collected by the traps from the water column during summer, but similar to values recorded during winter. This is further proof that winter sedimenting matter is indeed resuspended sediment. 


\section{DISCUSSION}

Material collected by sediment traps is equivalent to information integrated over time; hence the time scale of each measurement carried out on such material is much larger than when discrete samples are collected from the water column (Soutar et al., 1977). Thus, although the number of data presented here is only 5 per annum, these values can be regarded as representative of the whole year, which would certainly not be the case if the water column itself had been monitored the same number of times. However, since the results determined with traps depend on trap shape and current speed around the orifice, they do not necessarily give a correct picture of the actual sedimentation flux (Gardner, 1977). The performance of the traps used in this study has been discussed by Smetacek et al. (1978) who have shown that they tend to underestimate the actual sedimentation rate, and that the greater amounts collected by lower traps is not only due to resuspension but is also related to trap efficiency. The lower trap ( $2 \mathrm{~m}$ above bottom) generally collected more material, even during periods when resuspension was low; it is believed, therefore, that these results are more representative of the actual flux than those from the upper trap. Suprisingly, lesser amounts of chlorinated hydrocarbons were collected by the upper traps during 1976, but in 1977 the situation was reversed although discrepancies in the amounts collected by the two traps were less in 1977 than in 1976.

For all pesticides, the decline in input to the sediments from 1976 through 1977 is noteworthy. During 1977, less sedimenting material was collected by the traps than in 1976, and, although this could serve as a possible explanation for the accompanying decline in PCBs, the almost total absence of other organochlorine compounds from the 1977 material is in all probability due to other factors. The ban on the use of DDT and the restrictions on the use of other chlorinated hydrocarbon pesticides imposed by the states bordering the Baltic Sea during the past few years could possibly explain the decline in these compounds. The sporadic appearance of pesticides in particulate matter during 1976 is more likely related to input rates into the sea than to the autochthonous processes of particle formation and sedimentation within the water column. High concentrations of pesticides were recorded both during summer and winter when sedimentation regimes differ drastically.

Surface sediments contained measurable amounts of all the organochlorine compounds sought except DDD, and the ratios of these compounds to each other differed widely from those found in matter settling down the water column. Whether the fact that the PCBs content of sediments is relatively lower than that of the pesticides is due to differences in breakdown rates, or whether pesticide inputs in the past were higher than those during the period of investigation, is a matter of conjecture. The former effect seems more probable as the input of PCBs to the sediments was on average $0.19 \mathrm{ng}$ PCBs $\mathrm{mg}^{-1}$ of sedimenting matter during the two years of the investigation, and even if the upper $1 \mathrm{~cm}$ of sediment were mixed, the average content of PCBs in this $1 \mathrm{~cm}$ layer should be higher than the measured $0.0096 \mathrm{ng}$ PCBs $\mathrm{mg}^{-1}$ sediment (dry weight). Thus, in winter when sediment trap material consists largely of resuspended sediment, its content of PCBs is low to not detectable.

Not much information is present on the content of PCBs in the water column of Kiel Bight. The only data available were recorded in October in both 1974 and 1975 (Stadler and Ziebarth, 1976; Stadler, 1977). The content of PCBs averaged for both years was $3.1 \pm 2.7 \mathrm{ng} \mathrm{dm}^{-3}(\mathrm{n}=12)$ equivalent to $62 \times 10^{3} \mathrm{ng}$ $\mathrm{m}^{-2}$ for the $20-\mathrm{m}$ water column, which is the mean depth of the Bight. The PCBs present in the water column can be in various states ranging from dissolved to particulate (Dawson and Riley, 1977) and without knowledge of input rates, one can only speculate on residence times of the pollutants in the water column. However, annual rates of input of PCBs to the sediments as recorded by the $2-\mathrm{m}$ and $5-\mathrm{m}$ traps were $112 \times 10^{3}$ and $79 \times 10^{3} \mathrm{ng} \mathrm{m}^{-2} \mathrm{y}^{-1}$, respectively, in 1976; corresponding figures in 1977 were $24 \times 10^{3}$ and $33 \times 10^{3} \mathrm{ng} \mathrm{m}^{-2} \mathrm{y}^{-1}$. Thus, approximately twice to only a third of the content of PCBs in the water column settles out each year.

The seasonality of the rate of input to PCBs to the sediments is remarkable and is presumably due to the seasonality in input to the sea surface as well as to the annual cycle of sedimentation. There are'several pathways by which PCBs are introduced into the sea, of these the paint of ships (Jensen et al., 1972) is likely to be of importance in the Kiel Bight as it is situated on a major international shipping route. During the summer, the number of vessels increases considerably, as the Bight is a popular water sport resort. Although this source is difficult to quantify, it is possible that this seasonality in the recreation industry is one of the factors influencing the input of PCBs to the sediments.

It is well known that organisms concentrate chlorinated hydrocarbons and progressively accumulate them in their body tissue up the food chain (Olsson et al., 1973; Södergren, 1973; Parsons et al., 1977). The marked seasonality of PCB input to sediments can thus be attributed to the much higher activity of organisms during the summer. Most of the organic matter produced by phytoplankton spring and autumn blooms (March/April and October, respectively) enters the 
benthic food web as a result of mass sedimentation of cells. PCB input rates to sediments were low during these periods in both years. The pelagic food web develops during late spring and reaches its greatest complexity in late summer. The combination of high production and low rates of sedimentation in the intermediate period indicates that the organic matter is utilized mainly within the water column. The large number of filter feeders and the frequency with which organic matter is recycled within the pelagic food web (Smetacek, in preparation) would lead to the concentration of persistent chlorinated hydrocarbons in particulate residues of the food web. This is a further possible explanation for the seasonality of the PCBs : dry weight ratios of the sedimenting material.

This seasonality in PCB input to the sediments of Kiel Bight, whether related to the recreation industry, or to cumulatory effects of the pelagic web in summer, is likely to have an impact on the benthos because its biomass reaches its maximum in summer (Arntz, 1971). Thus, during the period of greatest food demand, the concentration of PCBs per unit food is the highest for the year.

Acknowledgements. The authors are grateful to Ms. M. Karl, Mr. G. Petrick and Mr. L. Uhlmann for their considerable assistance and to the crew of R. V. 'Littorina'. The Deutsche Forschungsgemeinschaft supplied financial support for this work.

\section{LITERATURE CITED}

Arntz, W. (1971): Biomasse und Produktion des Makrobenthos in den tieferen Teilen der Kieler Bucht im Jahre 1968. Kieler Meeresforsch. 27: 36-72

Aue, W. A., Hastings, C. R., Gerhardt, K. O. (1974). Gas chromatography on modified supports. J. Chromat. 99: $45-49$

Aue, W. A., Hastings, C. R., Kapila, S., Augl, J. M. (1973). Non-extractable polymer coatings (modified supports) for chromatography. J. Chromat. 87: 49-55

Bodungen, B. von (1975). Der Jahresgang der Nährsalze und der Primärproduktion des Planktons in der Kieler Bucht unter Berücksichtigung der Hydrographie. Dissertation, Universität Kiel

Bodungen, B. von, Bröckel, K. von, Smetacek, V., Zeitzschel, B. (1975). Ecological studies on the plankton in Kiel Bight. I. Phytoplankton. Merentutkimuslait. Julk./HavsforskIngsinst. Skr., Helsingfors 239: 179-186

Dawson, R., Riley, J. P. (1977). Chlorine-containing pesticides and polychlorinated biphenyls in British coastal waters. Estuar. \& Coast. Mar. Sci. 4: 55-69

Derenbach, J. (1969). Zur Homogenisation des Phytoplanktons für die Chlorophyllbestimmung. Kieler Meeesforsch. 25: $166-171$

Derenbach, J., Ehrhardt, M., Osterroht, C., Petrick, G. (1978). Sampling of dissolved organic material from seawater with reversedphase techniques. Mar. Chem. 6: 351-363

Gardner, W. D. (1977). Fluxes, dynamics and chemistry of particulates in the ocean. Ph. D. thesis, M. I. T./Woods
Hole Oceanographic Institution, Joint Program in Oceanography

Harvey, G. R., Steinhauer, W. G., Teal, J. M. (1973). Polychlorobiphenyls in North Atlantic Ocean water Science, N. Y 180: 643-644

Holden, A. V (1970). Source of polychlorinated biphenyl contamination in the marine environment. Nature, Lond. 228: $1220-1221$

Jensen, S., Renberg, L., Olsson, M. (1972). PCB contamination from boat bottom paint and levels of $\mathrm{PCB}$ in plankton outside a polluted area. Nature, Lond. 240: 358-360

Krey, J. (1961). Beobachtungen über den Gehalt an Mikrobiomasse und Detritus in der Kieler Bucht 1958-1960. Kieler Meeresforsch. 17: 163-175

Lenz, J. (1974). Untersuchung zum Nahrungsgefüge im Pelagial der Kieler Bucht. Der Gehalt an Phytoplankton, Zooplankton und organischem Detritus in Abhängigkeit von Wasserschichtung, Tiefe und Jahreszeit. Habilitationsschrift, Universität Kiel

Lenz, J. (1977). Hydrographic conditions. In: Rheinheimer, G. (ed.) Ecol. Stud. 25. Microbial ecology of a brackish water environment. Springer-Verlag, Berlin, pp. 12-25

Lorenzen, C. J. (1967). Determination of chlorophyll and phaeopigments: spectrophotometric equations. Limnol. Oceanogr. 12: 343-346

Olsson, M., Jensen, J. S., Renberg, L. (1973). PCBs in coastal areas of the Baltic. Reprint from PCB Conference II, National Swedish Environmental Protection Board Publications: $4 \mathrm{E}$

Osterroht, C. (1977). Dissolved PCB's and chlorinated hydrocarbon insecticides in the Baltic, determined by two different sampling procedures. Mar. Chem. 5: 113-121

Parsons, T. R., Takahashi, M., Hargrave, B. (1977). Biological oceanographic processes, 2nd ed., Pergamon Piess, Oxford

Smetacek, V. (1975). Die Sukzession des Phytoplanktons in der westlichen Kieler Bucht. Dissertation, Universität Kiel

Smetacek, V. (in press). Annual cycle of sedimentation in relation to plankton ecology in western Kiel Bight. Ophelia

Smetacek, V. Zooplankton standing stock, copepod faecal pellets and particulate detritus in Kiel Bight. Estuar. \& Coast. Mar. Sci. (submitted)

Smetacek, V., Bröckel, K. von, Zeitzschel, B., Zenk, W. (1978). Sedimentation of particulate matter during a phytoplankton spring bloom in relation to the hydrographical regime. Mar. Biol. 47: 211-226

Smetacek, V., Hendrikson, P. (1979). Composition of particulate organic matter in Kiel Bight in relation to phytoplankton succession. Oceanol. Acta 2: 287-298

Södergren, A. (1973). Transport, distribution and degradation of chlorinated hydrocarbon residues in aquatic model ecosystems. Oikos 23: 30-41

Soutar, A., Kling, S. A., Crill, P. A., Duffrin, E., Bruland, K. W. (1977). Monitoring the marine environment through sedimentation. Nature, Lond. 266: 136-139

Stadler, D. (1977). Chlorinated hydrocarbons in the seawater of the German Bight and the Western Baltic in 1975. Dt. hydrogr. Z. 30: 189-215

Stadler, D., Ziebarth, U. (1976). pp'DDT, Dieldrin and polychlorierte Biphenyle (PCB) im Oberflächenwasser der westlichen Ostsee 1974. Dt. hydrogr. Z. 29; 25-31

Strickland, J. D. H., Parsons, T. R. (1972). A practical handbook of sea-water analysis, 2nd ed, Bull. Fish. Res. Bd Can. 167: 1-310

UNESCO (1966). Determination of photosynthetic pigments in sea water. Monogr. oceanogr. Methodol. (UNESCO) 1: $1-66$ 
Walsh, G. E. (1972). Insecticides, herbicides and polychlorinated biphenyls in estuaries. J. Wash. Acad. Sci. 62: 122-139

Weil, L., Duré, G., Quentin, K. E. (1973). Adsorption von chlorierten Kohlenwasserstoffen an organischen Wassertrübstoffen und an Böden. Wasser-, Abwasserforsch. 4: $107-112$
Zeitzschel, B. (1965). Zur Sedimentation von Seston, eine produktionsbiologische Untersuchung von Sinkstoffen und Sedimenten der westlichen und mittleren Ostsee. Kieler Meeresforsch. 21: 55-80

Zeitzschel, B., Diekmann, P., Uhlmann, L. (1978). A new multisample sediment trap. Mar. Biol. 45: 285-288

This paper was submitted to the editor; it was accepted for printing on January 2, 1980. 